\title{
Bullying and health-related quality of life in children and adolescent Mexican students
}

\author{
"Bullying" e qualidade de vida relacionada com a saúde \\ de crianças e adolescentes escolares mexicanos
}

\author{
Carlos Alejandro Hidalgo-Rasmussen ${ }^{1}$ \\ Guadalupe Ramírez-López ${ }^{2}$ \\ Luis Rajmil $^{3}$ \\ Anne Skalicky ${ }^{4}$ \\ Alfredo Hidalgo-San Martín ${ }^{2}$
}

\footnotetext{
${ }^{1}$ Centro de Investigación en Riesgos y Calidad de Vida (CIRCAV), Centro Universitario de Sur, Universidad de Guadalajara. Av. Enrique Arreola Silva 883, Colonia Centro. 49.000 Ciudad Guzmán Jalisco México. carlos.hidalgo@ academicos.udg.mx ${ }^{2}$ Unidad de Investigación Epidemiológica y en Servicios de Salud de la Adolescencia, Instituto Mexicano del Seguro Social. Guadalajara Jalisco Mexico. ${ }^{3}$ Catalan Agency for Health Information, Assessment and Quality. Barcelona Spain.

${ }^{4}$ Evidera. Seattle WA United States.
}

\begin{abstract}
Previous studies have reported a relationship between being a victim of bullying, but no studies have been carried out with Mexican students; notwithstanding the high scores of bullying in Mexico in international rankings. The objective of this study was to analyze the association between being a victim of bullying and lower HRQoL among schoolchildren and adolescents in Mexico. This cross-sectional and correlational study involved 2225 students from 22 elementary, middle and high schools. HRQoL was assessed with the KIDSCREEN-10 questionnaire and bullying with the social adaptation dimension of KIDSCREEN-52. Bivariate associations were evaluated, and a multivariate logistic regression was utilized. The prevalence of victims of bullying was $17.3 \%$. Being a victim of bullying was double the risk of having a lower HRQoL than not being a victim after adjusting for health perception, gender and age, OR 2.3 (1.7-3.1). As the Wilson and Cleary Model of Quality of Life explains, individual characteristics, such as, being a victim of bullying are associated with quality of life. Similar findings in the existing literature imply that bullying is a global phenomenon that impacts the victimized child or adolescent's life in different ways.

Key words Bullying, Child, Adolescent, Quality of life, Violence
\end{abstract}

Resumo Pesquisas prévias informaram que ser vitima de "bullying" se associa à menor Qualidade de Vida Relacionada com a Saúde (QVRS); mas nenhuma foi realizada em estudantes Mexicanos apesar dos altos indices de "bullying" mostrados para o México nos rankings internacionais. O objetivo deste estudo foi analisar a associação entre ser vitima de "bullying" e QVRS. Este estudo transversal e de correlação incluiu 2225 crianças e adolescentes de 22 escolas de nível básico, médio básico e médio superior. A QVRS foi avaliada com o questionário KIDSCREEN-10 e o "bullying" com a dimensão de aceitação social do KIDSCREEN-52. Analisaram-se as associações bivariadas, verificou-se confusão e interação, e utilizou-se regressão logística multivariável. A prevalência de vitimas de "bullying" foi de 17.3\%. Ser vítima de "bullying" obteve um risco de mais do dobro de QVRS inferior que não ser vítima, depois de ajustar pela percepção de saúde, gênero e idade, OR 2.3 (1.7-3.1). No mesmo sentido que o referido pelo Modelo de Wilson e Cleary, em estudantes mexicanos com características individuais como ser vitima de "bullying", associam-se à QVRS, descoberta similar ao encontrado na literatura existente o que implica que o "bullying" é um fenômeno global que se reflete em diferentes aspectos da vida em crianças e adolescentes vitimizados.

Palavras-chave "Bullying", Criança, Adolescente, Qualidade de vida, Violência 


\section{Introduction}

Bullying is a distinct type of aggressive conduct that seeks to cause damage or discomfort to another person and is characterized by being intentional, repetitive, and in which there is an imbalance of power ${ }^{1}$. In Mexico bullying is a major public health problem. According to the Organization for Economic Cooperation and Development (OECD), in 2013, in primary schools in Mexico verbal abuse was present in $8.3 \%$ and physical abuse in $5.7 \%$ of schools. At the middle school level verbal abuse was present in $29.5 \%$ and physical in $10.8 \%$ of schools. At the high school level verbal abuse was present in 5.8\% and physical abuse in $1.4 \%$ of schools. It is noteworthy that comparing abuse in middle and high schools across all countries in the study, Mexico is ranked first in physical and second in verbal abuse $^{2,3}$. Among European and North-American countries, bullying has been observed in male adolescents more than in female adolescents, and as age increases, physical aggression shifts to verbal harassment ${ }^{4}$.

Bullying has negative social and psychological consequences for children and adolescents ${ }^{5-10}$ and is a risk factor for health related quality of life (HRQoL) which refers to the "physical and mental health perceived individually or in groups over time"11. The relationship between bullying and perceived lower HRQoL was first studied in Australian students, who had been victims of bullying, perceived a lower HRQoL ${ }^{12}$. In a later study of 11 European countries ${ }^{13}$ being a victim of bullying was associated with sadness and emotional instability measured by KIDSCREEN 52. It has also been observed that the support of peers and teachers influences the relationship between being a victim of bullying and satisfaction in life ${ }^{14}$. In Sweden ${ }^{15}$ victims of bullying reported lower energy and vitality, limitations in physical activities and scored lower in psychological wellbeing compared to those that had not been bullied. This Swedish study also found the number of affected HRQoL domains was greater among those who were harassed and in those of greater age. Lastly, in Norway ${ }^{16}$, it was found that bullying explained $2.6 \%$ of the HRQoL measured with KIDSCREEN-10.

Another variable associated with HRQoL is self-perception of health ${ }^{17}$; with perception of health worsening in children 12 years and old$\mathrm{er}^{18}$. Also having a disability was associated with a lower score in the physical domain of quality of life ${ }^{19}$ which worsens with age ${ }^{20}$. In clinical pop- ulations, body image has been associated with HRQoL in women ${ }^{21}$ and men ${ }^{22}$. In school-aged populations body image, a variable related with self-perception, along with bullying, have been associated with lower HRQoL scores ${ }^{16}$. Females perceive a lower HRQoL to males in the dimensions of physical and emotional well-being and in their relationship with their parents ${ }^{18}$. In general, it has been observed that quality of life is lower at lower socioeconomic levels ${ }^{23}$.

The purpose of our study was to analyze the association between being a victim of bullying and lower HRQoL in school age Mexican children and adolescents. This study considered the effects that bullying could have on HRQoL, independent from other factors, such as perceived heath, self-perception, disability, gender, age and socio-economic level.

\section{Methods}

An observational, cross-sectional study was carried out with students from elementary, middle and high schools in mid-sized cities (50000 to 1 million inhabitants approx.), small cities (15000 up to 50000) and mixed and rural localities (less than 15,000) from the south-central region of the state of Jalisco, Mexico, during years 2011 and 2012.

A non-probabilistic convenience sample was administered to employ an on-line questionnaire. Participating schools were required to have computer equipment and Internet connection. It was necessary to have support from the administrative authorities at these schools to distribute informed consent to parents. Students who were present the day of the administration of the questionnaire were those who participated in the study.

\section{Participants}

The sampling frame was comprised of students between 8 and 18 years of age attending fifth or sixth grade from five elementary schools and any grade from seven middle schools and ten high schools. An online, self-administered questionnaire was completed by all the students who were present on the day of the survey administration with parental consent (2735). Data from students who failed to answer all the questions about HRQoL or bullying (261) or any co-variables (249) were not included in the analysis, which respectively represents $9.5 \%$ and $9.1 \%$ of the total evaluated students. From 7413 matricu- 
lated students, a total of 2225 student questionnaires (30\%) were evaluated in the study.

\section{Instruments}

Aside from sociodemographic information, the KIDSCREEN-52 item version instrument was used ${ }^{24}$ adapted for use in different countries $^{25}$. The Mexican version was adapted by The KIDSCREEN Group in May of 2011 and its psychometric properties verified ${ }^{26}$. From this instrument, the ten item KIDSCREEN-10 $0^{27,28}$ was developed, and its' reliability and validity ${ }^{29}$ has been established, as well as the bullying and self-perception domains from the 52 item version, plus, the information on perceived health and disability that the instrument collects.

\section{Victims of bullying}

The KIDSCREEN social acceptance domain was used as the outcome variable $e^{27,28}$. This scale considers bullying behavior as when other student or group of students say or do nasty and unpleasant things to each other and this behavior is repeated ${ }^{25}$. This scale was utilized in two previous studies ${ }^{13,30}$.

The social acceptance domain includes three items: 1) Have you been afraid of other children? 2) Have other children made fun of you? 3) Have other children threatened or mistreated you?

The response options are on a 5 point Likerttype scale (never, hardly ever, sometimes, almost always, always). The three items are summed and weighed according to international data. The recall period was one week. European studies have reported that the scale has adequate validity and internal consistency ${ }^{31-33}$. In this study, the scale had a Cronbach's $\alpha$ of .71 already stated above.

To facilitate interpretation of the scores, the KIDSCREEN around 'social acceptance' domain but not earlier suggest be consistent was transformed to T-scores with a scale mean of 50 and a standard deviation (SD) of 10 . When scaling, the student's score (range: 1-5) was subtracted from the average of the European international group and divided by the SD. For example:\{([individual score on bullying - average of the reference group on bullying] /SD of the reference group) $\mathrm{x}$ $10+50\}^{24}$. Low scores indicate a greater perception of being a victim of bullying. A categorical variable was created and dichotomized using the $\mathrm{SD}$ as a cut-off point according to suggestions from previous studies ${ }^{13}$ and "victim of bullying" was coded as: no $=0$ and yes $=1$.

\section{Health-related Quality of Life}

The validated KIDSCREEN-10 instrument was used to evaluate the HRQoL ${ }^{29}$. For this study, Cronbach's $\alpha$ was .82, above the standard of .70 for groups ${ }^{34}$. The instrument included ten items: 1) Have you felt well and in shape? 2) Have you felt full of energy 3) Have you felt sad? 4) Have you felt alone? 5) Have you had enough time for yourself? 6) Have you been able to do the things that you wanted in your free time? 7) Have your parents treated you fairly? 8) Have you had fun with your friends? 9) Have you done well in school? 10) Have you been able to pay attention in class?

The instrument uses a 5-point Likert-type scale with response options from never to always. The recall period is the past week. The HRQoL variable was dichotomized using the first decile as the cut-off point as in previous reports ${ }^{29}$. For purposes of data interpretation, the HRQL variable was coded as: better $\mathrm{HRQoL}=0$ and lower $\mathrm{HRQOL}=1$.

Perceived health. Perceived health was measured using the question from the KIDSCREEN-52 questionnaire ${ }^{27,28}$ : In general, how would you say your health is? This question has been used to measure health in previous studies $^{18}$. The response options were on a 5-point Likert-type scale (from excellent to poor) and was coded as good/very good/excellent $=0$ and poor/fair $=1$.

Disability. Disability was evaluated with the question from the KIDSCREEN-52 questionnaire ${ }^{27,28}$ Do you have a chronic disability, illness or medical situation? The 5-point Likert scale was coded as: no $=0$, yes $=1$.

Self-perception. The self-perception domain from the KIDSCREEN-52 questionnaire ${ }^{27,28}$ examines self-perception and includes whether bodily appearance is seen positive or negatively. The body image domain explores how sure and satisfied one feels with oneself and self-appearance ${ }^{25}$. It includes five items: 1) Have you been happy with your way you are? 2) Have you been happy with your clothes? 3) Have you been worried about the way you look? 4) Have you felt jealous of the way other girls and boys look? 5) Would you like to change something about your body?

The answer options are on a 5 point Likerttype Scale (from never to always). A higher score indicates a better self-perception. A Cronbach's of .70 for the scale was calculated in this study. The variable self-perception was dichotomized using $1 \mathrm{SD}$ below the median as the cut-off, applying a stricter cut-off than the standard of 
one-half deviation suggested ${ }^{24}$. The variable was coded as high $=0$ and low $=, 1$. The self-perception scale was used due to its similarity with body image used in a previous study ${ }^{16}$.

Gender was coded as male $=0$, female $=1$. Exact age was obtained and coded as: 8-11 years $=0$ and $12-18$ years $=1$.

Socioeconomic level was calculated from parent's educational level and type of work and was classified as low, medium and high ${ }^{35}$. The variable was coded as: medium and high class $=0$, and low $=1$.

\section{Procedure}

After receiving permission from school authorities, parental consent was obtained. Psychology students in an advanced research course were trained about concepts of quality of life, instruments characteristics, administration procedures, and how to handle questions arising during administration. On the day of the survey, the trained students were assisted by teachers at each school and study participants were provided access to the computer room of their school. Students completed the self-administered, online questionnaire which required approximately 30 minutes to complete. During the survey administration, trained staff gave support to participants as needed.

Ethics

The Project was approved by the Bioethical Committee from the south campus (CUSUR) of University of Guadalajara, and carried out according to the principles of the Declaration of Helsinki on the International Ethical Standards for Biomedical Research on Human Beings. This research project was considered of "minimal risk" according to the General Health Law of Mexico. Once authorization was obtained from school authorities to carry out the research, written consent was asked of parents. The students were informed of the project and were told that their participation was voluntary and that the data would be handled confidentially and anonymously. Before beginning the questionnaire, informed assent was obtained from the students.

\section{Data analysis}

Descriptive statistics were carried out with means, standard deviations, medians, percentiles and percentages. To analyze the percentage differ- ences a chi-squared test or Fisher's exact was used. HRQoL did not have a normal distribution. The bullying variable was dichotomized using one standard deviation as coded in accordance with previous studies ${ }^{13}$ and coded: no $=0$ and yes $=1$.

To analyze the relationship between victims of bullying and HRQoL both a simple and multiple logistic regressions were used and odds ratios (OR) and 95\% confidence intervals (CI 95\%) were obtained. Interactions and confounding effects with the victims of bullying variable were verified with each of the covariates: perceived health, disability, negative self-perception, gender, age and socioeconomic level. Multiple logistic regression models were carried out with the backward elimination method. Categorical variables were coded and entered as 1 when the condition was the worst and 0 if the situation was better. For example, the code 1 signified being a victim of bullying, having a lower HRQoL or having fair/poor health. Multicollinearity was valued with the variance of inflation factor (considering 10 acceptable) and acceptable (considering less than 0.1 as a serious problem and 0.2 as a potential problem). A Hosmer-Lemeshow test was used to evaluate goodness-of-fit. The value $\mathrm{p}$ $<0.05$ was considered as statistically significant. The statistic software SPSS V20 (SPSS Inc., Chicago, IL, USA) was used to conduct the analysis.

\section{Results}

Participants in the study were 248 children 8 to 11 years of age $(11.1 \%)$ and $1977(88.9 \%)$ students old 12 to 18 years. All students were from 22 schools in the state of Jalisco, 50\% were from mid-sized cities, $31.8 \%$ from small cities and $18 \%$ from towns. The total number of students by school (S) were as follows: $\mathrm{S} 1(\mathrm{~N}=67), \mathrm{S} 2(\mathrm{~N}$ $=442), \mathrm{S} 3(\mathrm{~N}=390), \mathrm{S} 4(\mathrm{~N}=164), \mathrm{S} 5(\mathrm{~N}=282)$, S6 $(\mathrm{N}=254), \mathrm{S} 7(\mathrm{~N}=177), \mathrm{S} 8(\mathrm{~N}=1117), \mathrm{S} 9$ $(\mathrm{N}=1218), \mathrm{S} 10(\mathrm{~N}=450), \mathrm{S} 11(\mathrm{~N}=142), \mathrm{S} 12$ $(\mathrm{N}=344), \mathrm{S} 13(\mathrm{~N}=357), \mathrm{S} 14(\mathrm{~N}=132), \mathrm{S} 15$ $(\mathrm{N}=1852), \mathrm{S} 16(\mathrm{~N}=363), \mathrm{S} 17(\mathrm{~N}=766), \mathrm{S} 18$ $(\mathrm{N}=632), \mathrm{S} 19(\mathrm{~N}=488), \mathrm{S} 20(\mathrm{~N}=410), \mathrm{S} 21(\mathrm{~N}$ = 502), S22 (459). The student participants with complete data were $52.9 \%$ females and $47.1 \%$ males; $11.2 \%$ were between 8 and 11 years, $41.4 \%$ 12 to 15 years, and $47.4 \% 16$ to 18 years of age.

Seventeen percent $(17.3 \%)$ of students were victims of bullying. The majority of students perceived their health as good or very good and had a high score of self-perception, 7.4\% reported some disability; with similar male and female propor- 
tions. AThe predominant age was 12 to 18 years and medium socioeconomic strata (Table 1).

In the bivariate analysis (Table 1 ), being a victim of bullying increased the risk of having lower HRQoL by 2.5 times, and increased the risk by 4.3 times of the perception of having fair to poor health. In females the possibility of a lower HRQoL increased by 1.6 to 1.9 times in adolescents ages 12 to 18 . The remainder of the covariates did not demonstrate statistical significance.

In the multivariate analysis (Table 2) being a victim of bullying significantly increased the risk of having a lower HRQoL by 2.3 times, perception of having fair to poor health increased by 3.5 times, and for females the risk was increased by 1.5 times. The Hosmer-Lemeshow test did not show significant differences in the expected and observed values, indicating an adequate adjustment in the model.

According to the $\mathrm{R}^{2}$ values, the model explains $4 \%$ and $9 \%$ of the variance, respectively, for those corresponding to Cox and Snell or Nagelkerke. Collinearity was not present: tolerance $0.98 \mathrm{VIF}=1.02$.

\section{Discussion}

The main result of the study indicates that being a victim of bullying increased the possibility of having lower HRQoL in a model that also included perceived health, gender and age. In Mexico this relationship has not been studied before and it is important to examine how being a victim of bullying is related to the general aspects of student life.

\section{Prevalence of bullying}

The overall prevalence of victims of bullying was $17.3 \%$ which is lower than for Mexican students from elementary ${ }^{36}$ and similar to middle schools ${ }^{36-38}$ and within range found in European studies $(11.7 \% \text { to } 29.6 \%)^{13}$, using the KINDL-10 instrument.

Differences between countries in the prevalence of victims of bullying have also been found in studies. It has been argued that these differences may be attributed to cultural and social differences and distinct implementation of policies and programs related to bullying prevention ${ }^{4}$.
Table 1. Simple Logistic Regression Between Being a Victim of Bullying, Covariates and HRQoL in Mexican Children and Adolescents $(\mathrm{N}=2225)$.

\begin{tabular}{|c|c|c|c|}
\hline \multirow{2}{*}{ Predictor variables } & \multicolumn{3}{|c|}{ HRQoL } \\
\hline & N (\%) & $\mathrm{OR}_{\text {crude }}$ & 95\% CI \\
\hline \multicolumn{4}{|l|}{ Victim of bullying } \\
\hline No & $1840(82.7)$ & 1 & \\
\hline Yes & $385(17.3)$ & 2.54 & $1.85-3.50^{* * *}$ \\
\hline
\end{tabular}

Perceived health

$\begin{array}{rccc}\text { Good/very good/ } & 1970(88.5) & 1 & \\ \text { excellent } & & & \\ \text { Poor/fair } & 255(11.5) & 4.32 & 3.09-6.04^{* * *}\end{array}$

Disability

$$
\begin{array}{lrrr}
\text { No } & 2060(92.6) & 1 & \\
\text { Yes } & 165(7.4) & 1.29 & 0.77-2.14
\end{array}
$$

Self-perception

$\begin{array}{rrrr}\text { High } & 1821(73.6) & 1 & \\ \text { Low } & 653(26.4) & 0.86 & 0.62-1.21\end{array}$

Gender

$\begin{array}{rrrr}\text { Male } & 1047(47.1) & 1 & \\ \text { Female } & 1178(52.9) & 1.62 & 1.20-2.19^{* *}\end{array}$

Age

8-11 years $248(11.1) \quad 1$

12-18 years $1977(88.9) \quad 1.87 \quad 1.07-3.27^{*}$

Socioeconomic level

High and medium $1984(89.2) \quad 1$

Low $\quad 241(10.8) \quad 1.49 \quad 0.97-2.29$

OR, odds ratio; CI, confidence interval. HRQoL: Health-Related Quality of life, - cutoff point corresponds to the first decile $(0=$ higher HRQoL: T score $\geq 36.5,1=$ lower HRQoL: score $\mathrm{T}<36.5) .{ }^{*} \mathrm{p}<0.05,{ }^{* *} \mathrm{p}<0.01 \mathrm{y}^{* * *} \mathrm{p}<0.001$.

\section{Relation between being a victim of bullying and HRQoL}

Adolescents that experience bullying scored lower in HRQoL than those that did not. This relationship is independent from gender, age and perceived health effect. Previous studies have found this association ${ }^{12-16}$. The use of different instruments and methods of analysis complicate comparisons between studies. Nevertheless, it is worth noting that, in various studies ${ }^{12,14,15}$ lower scores from different domains of quality of life are associated with being a victim of bullying, and, with the KIDSCREEN-52 instrument, the "moods and emotions" domain appears most frequently in logistic regression models (7 of 11 countries).

The study findings contribute to the body of evidence that bullying is a risk factor of HRQoL and reinforces previous findings of the presence 
Table 2. Multiple Logistic Regression Model Between Being a Victim of Bullying and HRQoL in Mexican Children and Adolescents Adjusted for Covariates $(\mathrm{n}=2225)$.

\begin{tabular}{cccc}
\hline \multicolumn{1}{c}{ Predictor variables } & OR $_{\text {adjusted }}$ & $\mathbf{9 5 \% ~ C I}$ \\
\hline Victim of bullying & & & \\
& No & 1 & \\
Yes & 2.34 & $1.66-3.07^{\star * *}$
\end{tabular}

Perceived health

\begin{tabular}{|c|c|c|c|}
\hline & $\begin{array}{r}\text { Good/very good/ } \\
\text { excellent }\end{array}$ & 1 & \\
\hline \multirow{4}{*}{ Gender } & Poor/regular & 3.46 & $2.42-4.96^{\star * *}$ \\
\hline & & & \\
\hline & Male & 1 & \\
\hline & Female & 1.5 & $1.08-2.08^{\star}$ \\
\hline
\end{tabular}

Age

\begin{tabular}{rcc} 
Age & & \\
8-11 years & 1 & \\
$12-18$ years & 1.78 & $0.99-3.23$ \\
\hline Hosmer-Lemeshow & & 4.31 \\
goodness-of-fit, $X^{2}$ & & \\
P value & 0.37 \\
Cox \& Snell $R_{C S}^{2}$ & 0.04 \\
Nagelkerke $R_{N}^{2}$ & 0.09 \\
\hline
\end{tabular}

OR, odds ratio; CI, confidence interval. HRQoL: HealthRelated Quality of life, - cut off point corresponds to the first decile $(0=$ higher HRQoL: T score $\geq 36.5,1=$ lower HRQoL: T scores $<36.5){ }^{*} \mathrm{p}<0.05,{ }^{* * *} \mathrm{p}<0.001$.

of negative symptomatology in victims of bullying ${ }^{6}$.

Some theoretical models of HRQoL and life satisfaction may help explain these results. The Wilson and Cleary mode ${ }^{39}$ states that the characteristics of the individual influence the general perception of health and quality of life. In our results, being a victim of bullying and gender, as well as a lower perception of health, influence quality of life. Contrastingly, following Ferrans et al. ${ }^{40}$, individual factors exist that affect the quality of life; like biological, environmental, and social characteristics, such as socioeconomic levels. It is worth noting that disability, an individual characteristic related to a person's functional state described in Ferrans et al. model ${ }^{40}$, did not play a role in the multiple regression models examined in this study. This finding could be explained by the variability in the types of disability reported by students, the attention they were receiving for their disability at the time they answered the questionnaire or the opportunities to help mitigate their limitations offered by the school. Additionally, we expected self-perception to be part of the HRQoL model, considering a previous study on body image ${ }^{16}$; however, this was not the case. Another surprising finding was that socioeconomic level was not part of the HRQoL model. Type of occupation, level of education and income have previously been shown to be predictors of HRQoL, and income has been identified as the strongest predictor of the HRQoL ${ }^{23}$. The socioeconomic-level measure that we used was developed to include occupation and level of education, and therefore, an income variable was not incorporated in the model. In the study mentioned, there were differences in quality of life depending on the age of the child, whereby, for example, the level of education of the parents impact has more of an impact on children HRQoL compared to adolescents.

It is possible that low HRQoL is a contributing risk factor for bullying, as a reflection of exposure to frustrations and unpleasant situations as explained by theories of aggression and frustration-aggression ${ }^{41}$. This explanation, though, may be more linked to the harasser than the victim to whom our study was directed.

Previous research has found that bullying has a negative impact on individuals and in this study evidence found a similar impact on HRQoL in Mexican students. Considering the life course model $^{42}$ it is possible that in bullying victims, the lack of social abilities, or having a weak family or negative peers networks, or a lack of personal resources or having experienced influencing life events, like the act of being intimidated or harassed, can have an impact on hedonistic experiences, and can lead to unhappiness in children and adolescents.

Our findings are similar to a recent study on bullying influences in adolescents aged 15-17 years, using a qualify of life utility measure, where scores were significantly lower in victims of bullying $^{43}$. Another recent study found that school violence negatively affects HRQoL, but bullying was the variable least predictive to $\mathrm{HRQOL}^{44}$. Although these studies reported similar findings, the differences in instruments and analyses need to be considered.

\section{Limitations}

Since the study is cross-sectional, causal relations cannot be determined. The analytic sample included only those students who completed the questionnaire; students who did not answer the complete questionnaire or students who were not present on the day of the survey were excluded. 
No information is available on the children and adolescents that did not participate in the study.

Even though this study included a wide diversity of students by age, gender and school type, since it uses a convenience sample, the results of the study are not representative of students in the base population.

The administration of the questionnaire required computers and Internet connection, and several schools which did not have such equipment could not participate in the study. Therefore, schools with fewer resources may not be reflected in these results. In addition, students who, due to a lower socioeconomic level, may not have had computer skills necessary to answer the questionnaire or understand how to answer the questionnaire may have chosen not to participate.

Students may have tended to answer in a favorable way, creating social desirability bias. Nevertheless, the use of self-report surveys is common, necessary and efficient when collecting data from a large sample. Although the study of bullying has been going on for decades, the designation as to who is a victim of bullying depends on the instrument used, recall period and the definition of bullying ${ }^{1}$.

\section{Conclusions}

The contributions of this study to the literature is to report for the first time the association between victims of bullying and HRQoL in a Mexican population of schoolchildren and adolescents. Also, this study used a cross-culturally adapted instrument which allows for direct comparison of cultural differences in HRQoL and bullying.

Future studies should focus on longitudinal study design to understand temporal associations between HRQoL and bullying. For the school community, student HRQoL could possibly serve as an indicator of bullying problems since low student quality of life may contribute to worsening conditions in which aggression is fostered.
Similarly, adolescents who are bullied, may be more sensitive to peer behavior or have mental health problems and are more likely to be victims of bullying ${ }^{43}$. An approach strategy might be to focus on adolescents who have these characteristics. Nevertheless, addressing multiple factors such as the student's relationship with the teacher, school policies, and neighborhoods may have more impact on adolescent quality of life ${ }^{44}$. Another important factor to highlight could be the important role of school Principals in the directing the social norms at a school ${ }^{3}$. At a policy level, it is important that Mexican Ministries of Education and Health work together on strategies and legislation to prevent bullying. There is a need to focus on the victims of bullying. Not only is there a need to focus on bullying victims, but also on enhancing students' lives to diminish the effects of bullying.

\section{Collaborations}

CA Hidalgo-Rasmussen: design and conception of the study, data collection, statistical analysis and interpretation, preparation of the manuscript and approval of the final version. AM Skalicky: interpretation of data, critical review of the manuscript and revision of the final version. A Hidalgo-San Martín: conception of the study, critical revision of the manuscript and approval of the final version. G Ramírez-López: statistical analysis, critical review of the manuscript content and approval of the final version. L Rajmil: interpretation of data, critical review of the manuscript, approval of the final version. 


\section{References}

1. Olweus D. School bullying: development and some important challenges. Annu Rev Clin Psychol [Internet]. 2013 [cited 2014 Jul 9];9(1):751-80. Available from: http://www.ncbi.nlm.nih.gov/pubmed/23297789

2. Organization for Economic Cooperation and Development (OECD). Talis 2013, Base de datos [Internet]. 2013. [cited 2014 Jul 9]. Available from: http://www. inee.edu.mx/images/stories/2015/mesa-Talis/presentacion/Anexo_TALIS_2013_web.pdf

3. Organization for Economic Cooperation and Development (OECD). Talis 2013 Results: An International Perspective on Teaching and Learning. Paris: OECD Publishing; 2014.

4. Craig W, Harel-Fisch Y, Fogel-Grinvald H, Dostaler S, Hetland J, Simons-Morton B, Molcho M, de Mato M, Overpeck M, Due P, Pickett W. A cross-national profile of bullying and victimization among adolescents in 40 countries. Int J Public Health 2009; 54(Supl. 2):216-224.

5. Olweus D. Harassment and threatening behavior among school children. Madrid: Alfaomega; 2004.

6. Due P, Holstein BE, Lynch J, Diderichsen F, Gabhain SN, Scheidt P, Currie C, Health Behavior in SchoolAged Children Bullying Working Group. Bullying and symptoms among school-aged children: International comparative cross sectional study in 28 countries. Eur $J$ Public Health 2005; 15(2):128-132.

7. Gobina I, Zaborskis A, Pudule I, Kalnins I, Villerusa A. Bullying and subjective health among adolescents at schools in Latvia and Lithuania. Int J Public Health 2008; 53(5):272-276.

8. Penning SL, Bhagwanjee A, Govender K. Bullying boys: the traumatic effects of bullying in male adolescent learners. J Child Adolesc Ment Health [Internet]. National Inquiry Services Centre (NISC); 2010 Nov 11 [cited 2014 Jul 9];22(2):131-143. Available from: http:// r4d.dfid.gov.uk/Output/189121/Default.aspx

9. Loredo-Abdalá A, Perea-Martínez A, López-Navarrete GE. "Bullying”. Peer violence. A real problem in adolescents. Acta Pediatr Mex 2008; 29(4):210-214.

10. Valadez I, Amezcua R, González N, Montes R, Vargas $\mathrm{V}$. Peer mistreatment and suicide attempt in adolescents that go to School. Rev Latinoam Ciencias Soc Niñez y Juv [Internet]. Centro de Estudios Avanzados en Niñez y Juventud; 2011 [cited 2014 Aug 7];9(2):783796. Available from: http://www.redalyc.org/resumen. oa?id $=77321592020$

11. Centers for Disease Control and Prevention. Measuring Healthy Days [Internet]. Atlanta; 2000 [cited 2014 Sep 17]. Available from: http://www.cdc.gov/hrqol/pdfs/ mhd.pdf

12. Wilkins-Shurmer A, O'Callaghan MJ, Najman JM, Bor W, Williams GM, Anderson MJ. Association of bullying with adolescent health-related quality of life. J Paediatr Child Health [Internet]. 2003 Aug [cited 2014 Jul 9];39(6):436-441. Available from: http://www.ncbi. nlm.nih.gov/pubmed/12919497

13. Analitis F, Velderman MK, Ravens-Sieberer U, Detmar S, Erhart M, Herdman M, Berra S, Alonso J, Rajmil L; European Kidscreen Group. Being bullied: associated factors in children and adolescents 8 to 18 years old in 11 European countries. Pediatrics [Internet]. 2009 Feb [cited 2014 Jun 18];123(2):569-577. Available from: http://www.ncbi.nlm.nih.gov/pubmed/19171624
14. Flaspohler PD, Elfstrom JL, Vanderzee KL, Sink HE, Birchmeier Z. Stand by me: The effects of peer and teacher support in mitigating the impact of bullying on quality of life. Psychol Sch 2009; 46(7):636-649.

15. Frisén A, Bjarnelind S. Health-related quality of life and bullying in adolescence. Acta Paediatr [Internet]. 2010 Apr [cited 2014 Jul 9];99(4):597-603. Available from: http://www.ncbi.nlm.nih.gov/pubmed/20085553

16. Haraldstad K, Christophersen KA, Eide H, Nativg GK, Helseth S. Predictors of health-related quality of life in a sample of children and adolescents: A school survey. J Clin Nurs 2011; 20(21-22):3048-3056.

17. Zullig KJ, Valois RF, Drane JW. Adolescent distinctions between quality of life and self-rated health in quality of life research. Health Qual Life Outcomes [Internet]. 2005 Jan [cited 2014 Jul 19];3:64. Available from: http://www.pubmedcentral.nih.gov/articlerender.fcgi?artid $=1280929 \&$ tool $=$ pmcentrez\&rendertype $=a b-$ stract

18. Vélez Galárraga R, López Águila S, Rajmil L. Gender and self-perceived health in chilhood and adolescence in Spain. Gac Sanit [Internet]. 2009 Sep-Oct [cited 2014 Jul 20];23(5):433-439. Available from: http:// www.ncbi.nlm.nih.gov/pubmed/19647349

19. Lin JH, Ju YH, Lee SJ, Lee CH, Wang HY, Teng YL, Lo SK. Do physical disabilities affect self-perceived quality of life in adolescents? Disabil Rehabil 2009; 31(3):181188.

20. Lin JH, Ju YH, Lee SJ, Yang YH, Lo SK. Examining changes in self-perceived quality of life in children and adolescents with physical disability using a longitudinal design. Disabil Rehabil 2011; 33(19-20):1873-1879.

21. Hopwood P, Fletcher I, Lee A, Al Ghazal S. A body image scale for use with cancer patients. Eur J Cancer [Internet]. 2001[cited 2014 Jul 19];37(2):189197. Available from: http://www.ncbi.nlm.nih.gov/ pubmed/11166145

22. Harrington JM. Implications of treatment on body image and quality of life. Semin Oncol Nurs 2011; 27(4):290-299.

23. Von Rueden U, Gosch A, Rajmil L, Bisegger C, Ravens-Sieberer U. Socioeconomic determinants of health related quality of life in childhood and adolescence: results from a European study. J Epidemiol Community Health 2006; 60(2):130-135.

24. The Kidscreen Group Europe. The KIDSCREEN questionnaires: Quality of life questionnaires for children and adolescents. Lengerich: Pabst Science Publishers; 2006.

25. Ravens-Sieberer U, Herdman M, Devine J, Otto C, Bullinger M, Rose M, Klasen F. The European KIDSCREEN approach to measure quality of life and well-being in children: development, current application, and future advances. Qual Life Res [Internet]. 2014 Apr [cited 2014 Jul 9];23(3):791-803. Available from: http://www.pubmedcentral.nih.gov/articlerender. fcgi artid $=3953538 \&$ tool $=$ pmcentrez\&rendertype $=$ abstract

26. Hidalgo-Rasmussen CA, Rajmil L, Espinoza RM. [Cross-cultural adaptation of the KIDSCREEN questionnaire to measure health-related quality of life in the 8 to18 year-old Mexican population]. Cien Saude Colet [Internet]. 2014 Jul [cited 2014 Jul 15];19(7):22152224. Available from: http://www.ncbi.nlm.nih.gov/ pubmed/25014300 
27. Aymerich M, Berra S, Guillamón I, Herdman M, Alonso J, Ravens-Sieberer U, Rajmil L. [Development of the Spanish version of the KIDSCREEN, a health-related quality of life instrument for children and adolescents]. Gac Sanit [Internet]. 2005 Apr [cited $2014 \mathrm{Jul}$ 17];19(2):93-102. Available from: http://linkinghub. elsevier.com/retrieve/pii/S0213911105713364

28. Ravens-Sieberer U, Gosch A, Rajmil L, Erhart M, Bruil J, Power M, Duer W, Auquier P, Cloetta B, Czemy L, Mazur J, Czimbalmos A, Tountas Y, Hagquist C, Kilroe J. The KIDSCREEN-52 quality of life measure for children and adolescents: psychometric results from a cross-cultural survey in 13 European countries. Value Health [Internet]. 2008 [cited 2014 Jul 9];11(4):645658. Available from: http://www.ncbi.nlm.nih.gov/ pubmed/18179669

29. Ravens-Sieberer U, Erhart M, Rajmil L, Herdman M, Auquier P, Bruil J, Power M, Duer W, Abel T, Czemy L, Mazur J, Czimbalmos A, Tountas Y, Hagquist C, Kilroe J. Reliability, construct and criterion validity of the KIDSCREEN-10 score: a short measure for children and adolescents' well-being and health-related quality of life. Qual Life Res [Internet]. 2010 Jul 30 [cited 2015 Oct 1];19(10):1487-1500. Available from: http://link. springer.com/10.1007/s11136-010-9706-5

30. Hidalgo-Rasmussen C, Molina T, Molina R, Sepúlveda R, Martínez V, Montaño R, González E, George M. [Influence of bullying on the quality of life perception of Chilean students]. Rev Med Chil [Internet]. 2015 Jun [cited 2015 Sep 9];143(6):716-723. Available from: http://www.ncbi.nlm.nih.gov/pubmed/26230554

31. Tebe C, Berra S, Herdman M, Aymerich M, Alonso J, Rajmil L. [Reliability and validity of the Spanish version of the KIDSCREEN-52 for child and adolescent population]. Med Clin [Internet]. 2008 May [cited 2015 Sep 10];130(17):650-654. Available from: http://www. elsevier.es/es-revista-medicina-clinica-2-linkresolver-fiabilidad-validez-version-espanola-del-13120999

32. Ravens-Sieberer U, Herdman M, Devine J, Otto C, Bullinger M, Rose M, Klasen F. The European KIDSCREEN approach to measure quality of life and well-being in children: development, current application, and future advances. Qual Life Res [Internet]. 2014 [cited 2015 Sep 10];23(3):791-803. Available from: http://www.pubmedcentral.nih.gov/articlerender.fcgi?artid $=3953538 \&$ tool $=$ pmcentrez\&rendertype $=$ abstract

33. Haraldstad K, Christophersen K-A, Eide H, Nativg GK, Helseth S. Health related quality of life in children and adolescents: reliability and validity of the Norwegian version of KIDSCREEN-52 questionnaire, a cross sectional study. Int J Nurs Stud [Internet]. 2011 May [cited 2014 Jul 9];48(5):573-81. Available from: http://www. ncbi.nlm.nih.gov/pubmed/21067750

34. Aaronson N, Alonso J, Burnam A, Lohr KN, Patrick DL, Perrin E, Stein RE. Assessing health status and quality-of-life instruments: attributes and review criteria. Qual Life Res [Internet]. 2002 May [cited 2015 Aug 13];11(3):193-205. Available from: http://www.ncbi. nlm.nih.gov/pubmed/12074258

35. Rivas-Torres R, Bianchi-Águila R. The socioeconomic status on the research. Rev Asoc Mex Enf Metab Obes 1991; 2(1):44-45.
36. Román M, Murillo FJ. Latin America: school bullying and academic achievement. CEPAL Rev [Internet]. 2011 Aug [cited 2015 Aug 14] ;(104):37-53. Available from: http://repositorio.cepal.org/bitstream/handle/11362/11502/104037053I_en.pdf?sequence=1\&isAllowed $=\mathrm{y}$

37. Avilés-Dorantes DS, Zonana-Nacach A, Anzaldo-Campos MC. [Prevalence of bullying among students at a public secondary school]. Salud Publica Mex [Internet]. Instituto Nacional de Salud Pública; 2012 Aug [cited 2015 Oct 26];54(4):362-363. Available from: http://www.scielosp.org/scielo.php?script=sci_arttext\&pid=S0036-36342012000400002\&lng=en\&n$\mathrm{rm}=\mathrm{iso} \& \mathrm{t} \operatorname{lng}=\mathrm{es}$

38. Joffre-Velázquez VM, García-Maldonado G, Saldívar-González AH, Martínez-Perales G, Lin-Ochoa D, Quintanar-Martínez S, Vilasana-Gerra A. Bullying in junior high school students: general characteristics and associated risk factors. Bol Med Hosp Infant Mex [Internet]. 2011 Jun [cited 2015 Oct 26];68(3):177-185. Available from: http://www.scielo.org.mx/pdf/bmim/ v68n3/en_v68n3a4.pdf

39. Wilson IB, Cleary PD. Linking clinical variables with health-related quality of life. A conceptual model of patient outcomes. JAMA [Internet]. 1995 Jan 4 [cited 2014 Jul 9];273(1):59-65. Available from: http://www. ncbi.nlm.nih.gov/pubmed/7996652

40. Ferrans CE, Zerwic JJ, Wilbur JE, Larson JL. Conceptual Model of Health-Related Quality of Life. J Nurs Scholarsh [Internet]. 2005 Dec [cited 2015 Sep 27];37(4):336-42. Available from: http://doi.wiley. com/10.1111/j.1547-5069.2005.00058.x

41. Berkowitz L. Frustration-aggression hypothesis: examination and reformulation. Psychol Bull [Internet]. 1989 Jul [cited 2014 Aug 8];106(1):59-73. Available from: http://www.ncbi.nlm.nih.gov/pubmed/2667009

42. Veenhoven R. The Study of Life Satisfaction. In: Saris WE, Veenhoven R, Scherpenzeel AC, Bunting B, editors. A comparative study of satisfaction with life in Europe. Eötvös: University Press; 1996. p. 11-48.

43. Beckman L, Svensson M, Frisén A. Preference-based health-related quality of life among victims of bullying. Qual Life Res 2015; 25(2):303-309.

44. Higuita-Gutiérrez LF, Cardona-Arias JA. Predictive Modeling of Quality of Life, Family Dynamics, and School Violence in Adolescent Students from Medellín, Colombia, 2014. School Ment Health [Internet]. 2016 Mar 1 [cited 2016 Mar 27]; Available from: http://link. springer.com/10.1007/s12310-016-9190-3

Artigo apresentado em 04/11/2015

Aprovado em 10/08/2016

Versão final apresentada em 12/08/2016 
